\title{
Complete genome sequence of Thermus brockianus GE-1 reveals key enzymes of xylan/xylose metabolism
}

\author{
Christian Schäfers D, Saskia Blank, Sigrid Wiebusch, Skander Elleuche and Garabed Antranikian*
}

\begin{abstract}
Thermus brockianus strain GE-1 is a thermophilic, Gram-negative, rod-shaped and non-motile bacterium that was isolated from the Geysir geothermal area, Iceland. Like other thermophiles, Thermus species are often used as model organisms to understand the mechanism of action of extremozymes, especially focusing on their heat-activity and thermostability. Genome-specific features of T. brockianus GE-1 and their properties further help to explain processes of the adaption of extremophiles at elevated temperatures. Here we analyze the first whole genome sequence of T. brockianus strain GE-1. Insights of the genome sequence and the methodologies that were applied during de novo assembly and annotation are given in detail. The finished genome shows a phred quality value of QV50. The complete genome size is $2.38 \mathrm{Mb}$, comprising the chromosome (2,035,182 bp), the megaplasmid pTB1 (342,792 bp) and the smaller plasmid pTB2 (10,299 bp). Gene prediction revealed 2,511 genes in total, including 2,458 protein-encoding genes, 53 RNA and 66 pseudo genes. A unique genomic region on megaplasmid pTB1 was identified encoding key enzymes for xylan depolymerization and xylose metabolism. This is in agreement with the growth experiments in which xylan is utilized as sole source of carbon. Accordingly, we identified sequences encoding the xylanase Xyn10, an endoglucanase, the membrane $A B C$ sugar transporter $X y \mid H$, the xylose-binding protein $X y \mid F$, the xylose isomerase $X y \mid A$ catalyzing the first step of xylose metabolism and the xylulokinase XyIB, responsible for the second step of xylose metabolism. Our data indicate that an ancestor of T. brockianus obtained the ability to use xylose as alternative carbon source by horizontal gene transfer.
\end{abstract}

Keywords: Whole genome sequence, de novo assembly, Thermus, Thermus brockianus, Xylan degradation, Xylose metabolism, Thermophiles, Single molecule real-time sequencing

\section{Introduction}

Members of the genus Thermus are Gram-negative, rod-shaped, non-sporulating, thermophilic aerobic bacteria. They have been discovered from various environments with elevated temperatures, including hot springs, deep-sea hot vents, volcanic eruptions and solfatara fields [1-4]. Thermus aquaticus was first isolated in 1969 in hot springs in Yellowstone National Park, USA [5]. Thermus species and their produced enzymes, so called extremozymes, have attracted the attention of scientists from academia and industry due to their unique properties and metabolic pathways. Robust biocatalysts are attractive to various applications that

\footnotetext{
*Correspondence: antranikian@tuhh.de

Institute of Technical Microbiology, Hamburg University of Technology (TUHH), Kasernenstraße 12, 21073 Hamburg, Germany
}

often prevail in industrial processes [6-8]. The most prominent example of an industrial-relevant extremozyme is the DNA polymerase from $T$. aquaticus that is applied in polymerase chain reaction. Further industrial applications using enzymes from Thermus species include laundry detergents, DNA clean up prior to PCR or C-terminal sequencing [9-12]. Recently two glycoside hydrolases from $T$. antranikianii and T. brockianus were described and extended this group of industrial-relevant enzymes [13].

T. brockianus strain GE-1 was chosen for whole genome sequencing due to its ability to use xylan as sole carbon source and degrade xylan-rich substrates (Blank and Antranikian, unpublished results) [14]. To our knowledge the hydrolysis of xylan has not been described for any other T. brockianus strain so far, including type strain $\mathrm{YS} 038^{\mathrm{T}}$ [15]. With the description of 
the corresponding thermostable xylanase, Xyn10, we already identified and characterized one of the key enzymes in a putative xylan degradation pathway of $T$. brockianus GE-1 [14]. The identification and characterization of other polymer degrading enzymes from Thermus species is of great interest since there are only few reports regarding this aspect $[16,17]$. Especially in the view of finding new solutions for global challenges like degradation of xenobiotic compounds or providing novel renewable energy sources, the xylanolytic behavior of $T$. brockianus GE-1 justifies further examination. These findings will also contribute to the development of biotechnological processes based on lignocellulose as carbon source (biorefinery). In this paper we present the first whole genome sequence of a $T$. brockianus strain with finished grade status, showing a phred quality value of QV50.

\section{Organism information}

\section{Classification and features}

T. brockianus type strain $\mathrm{YS}_{0} 38^{\mathrm{T}}$ has been described as a member of the family Thermaceae within the phylum Deinococcus-Thermus. The isolate GE-1 could be clearly assigned to the species $T$. brockianus based on sequence information and 16S rRNA pairwise alignment, indicating 100\% identity in 1,476 nucleotides overlap. The phylogenetic classification of T. brockianus GE-1 within the Deinococcus-Thermus group is displayed in the phylogenetic tree shown in Fig. 1. Further alignments with closely related species of the genus Thermus were performed using the webserver LALIGN [18] and revealed the following results: T. igniterrae strain RF-4 T (96.8\% identity in 1,477 nts overlap), T. aquaticus strain YT-1 (96.1\% identity in 1,474 nts overlap), T. composti strain K-39 (96.1\% identity in 1,445 nts overlap), T. islandicus strain PRI-3838 (95.9\% identity in 1,445 nts overlap), T. arciformis strain TH92 (95.7\% identity in 1,484 nts overlap), T. caliditerrae strain YIM 77925 (95.0\% in 1,514 nts overlap), $T$. amyloliquefaciens strain YIM 77409 (94.9\% identity in 1,513 nts overlap), T. scodoductus (94.9\% identity in 1,476 nts overlap), T. thermophilus strain HB8 (94.9\% identity in 1,518 nts overlap), T. antranikianii strain HN3-7 T $(94.7 \%$ identity in 1,482 nts overlap), T. filiformis (94.0\% in 1,475 nts overlap) and $T$. oshimai SPS-17 T (91.4\% identity in 1,477 nts overlap).

T. brockianus strain GE-1 is a Gram-negative, rodshaped, non-pathogenic and non-sporulating bacterium (Fig. 2). This strain is aerobic, yellow pigmented and non-motile (Table 1). Due to their thermophilic characters, Thermus species are capable of thriving at elevated temperatures in a range between $45{ }^{\circ} \mathrm{C}$ and $83{ }^{\circ} \mathrm{C}$ and most species show an optimal growth at $80{ }^{\circ} \mathrm{C}$ [19]. While most of the species within the Thermus genus were reported to degrade a diverse set of sugars, including D-glucose, D-fructose, D-galactose, D-ribose, lactose and sucrose, only a few strains such as T. brockianus $\mathrm{YS} 038^{\mathrm{T}}$ or T. thermophilus HB8 were described to utilize D-xylose [15]. However growth on xylan was only reported for the strain T. brockianus GE-1 and a corresponding xylanase-encoding gene has been identified within its genome (Blank and Antranikian, unpublished results) [14]. T. brockianus strain GE-1 was isolated from

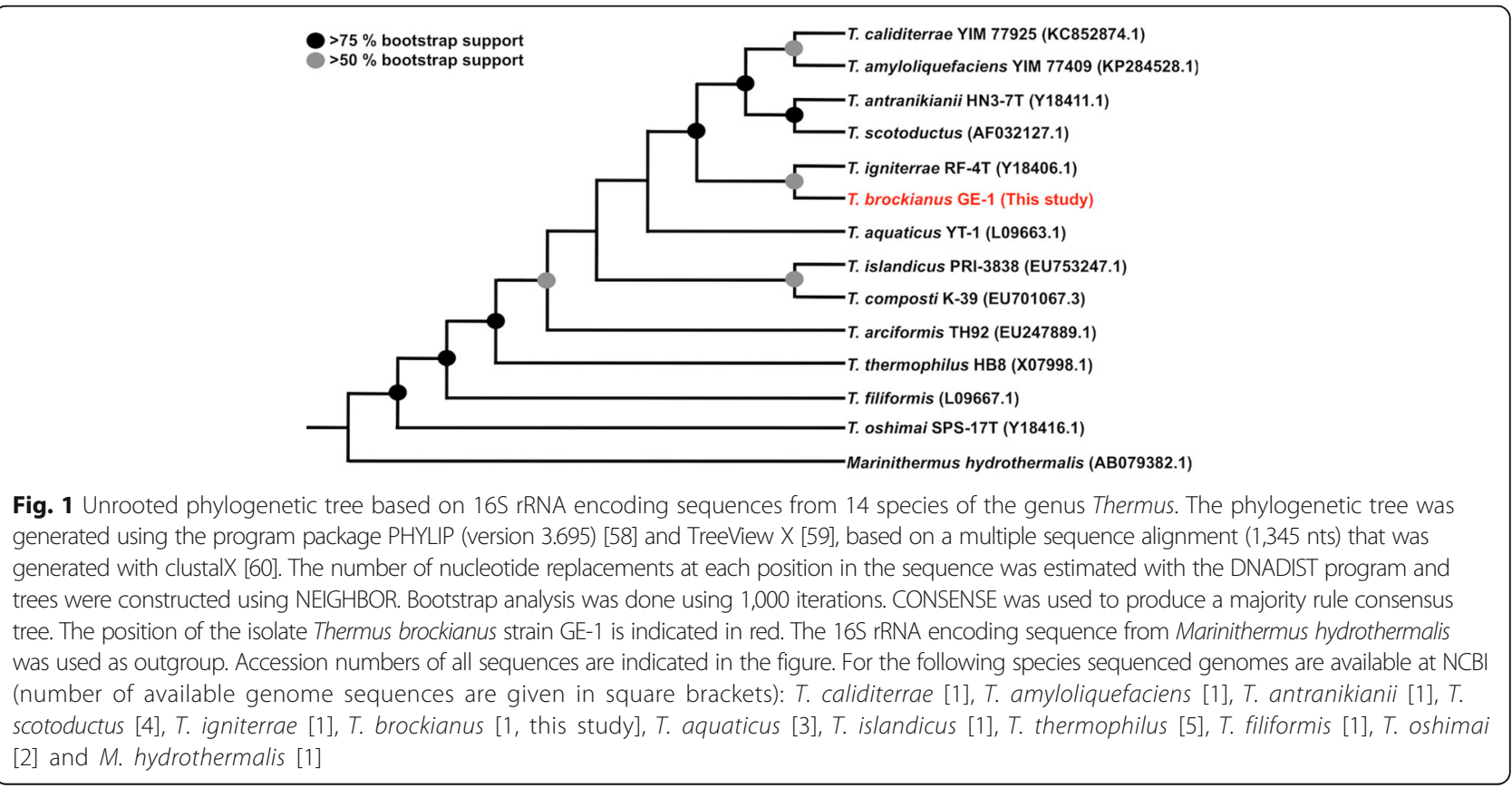




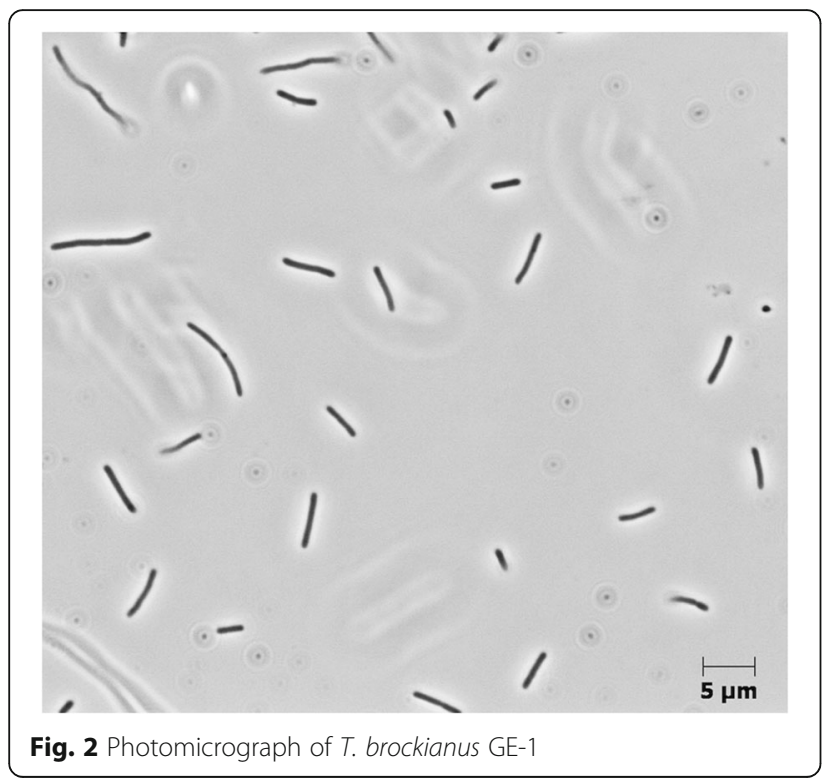

the Geysir geothermal area, Iceland. It optimally grows at a temperature of $70{ }^{\circ} \mathrm{C}$ and $160 \mathrm{rpm}$. The minimum information about the genome sequence (MIGS) [20] of that strain is shown in Table 1.

\section{Genome sequencing information}

\section{Genome project history}

We conceived the whole de novo genome sequencing of T. brockianus GE- 1 because of its ability to degrade xylan-rich biomass that has not been described for any other T. brockianus species so far and thus it has great potential for application in future biorefineries. Comparison of its genome sequence to that of other sequenced Thermus species will also help to understand general molecular features of xylan degradation in thermophiles. Sequencing was done at GATC Biotech AG (Konstanz, Germany). The de novo assembly, annotation and finishing of the whole genome of $T$. brockianus GE-1 was performed at the Institute of Technical Microbiology at Hamburg University of Technology (TUHH). The finished genome sequence, including three circular replicons, has been submitted to National Center of Biotechnology Information (NCBI) in June 2016. A summary of the project information is shown in Table 2.

\section{Growth conditions and genomic DNA preparation}

T. brockianus strain GE-1 was obtained from the strain culture collection of the Institute of Technical Microbiology at Hamburg University of Technology (TUHH). Deposition of the strain in the German National Culture Collection (DSMZ) is in progress. The strain was grown aerobically in DSMZ medium 878 (Thermus 162 medium) at $70{ }^{\circ} \mathrm{C}$ for at least $48 \mathrm{~h}$ and agitation speed of $160 \mathrm{rpm}$ [19]. The genomic DNA of T. brockianus GE-1
Table 1 Classification and general features of $T$. brockianus GE-1 according to MIGS [20]

\begin{tabular}{|c|c|c|c|}
\hline MIGS ID & Property & Term & Evidence code $\mathrm{a}^{\mathrm{a}}$ \\
\hline & Classification & Domain Bacteria & TAS [48] \\
\hline & & $\begin{array}{l}\text { Phylum Deinococcus- } \\
\text { Thermus }\end{array}$ & $\operatorname{TAS}[49,50]$ \\
\hline & & Class Deinococci & TAS $[51,52]$ \\
\hline & & Order Thermales & TAS $[51,53]$ \\
\hline & & Family Thermaceae & TAS $[51,54]$ \\
\hline & & Genus Thermus & $\operatorname{TAS}[5,49,55]$ \\
\hline & & $\begin{array}{l}\text { Species Thermus } \\
\text { brockianus }\end{array}$ & TAS [56] \\
\hline & & Strain GE-1 & IDA \\
\hline & Gram stain & Negative & IDA \\
\hline & Cell shape & Rod & IDA \\
\hline & Motility & Non-motile & NAS \\
\hline & Sporulation & Non-sporulating & NAS \\
\hline & Temperature range & $45-83^{\circ} \mathrm{C}$ & TAS [19] \\
\hline & Optimum temperature & $70^{\circ} \mathrm{C}$ & TAS [19] \\
\hline & pH range; Optimum & $\mathrm{pH} 7.0-\mathrm{pH} 8.0$ & NAS \\
\hline & Carbon source & Diverse set of sugars & IDA \\
\hline MIGS-6 & Habitat & Terrestrial hot springs & IDA \\
\hline MIGS-6.3 & Salinity & Not reported & \\
\hline MIGS-22 & Oxygen requirement & Aerobic & NAS \\
\hline MIGS-15 & Biotic relationship & Free-living & NAS \\
\hline MIGS-14 & Pathogenicity & Non-pathogen & NAS \\
\hline MIGS-4 & Geographic location & $\begin{array}{l}\text { Geysir geothermal } \\
\text { area, Iceland }\end{array}$ & IDA \\
\hline MIGS-5 & Sample collection & 1992 & IDA \\
\hline MIGS-4.1 & Latitude & Not reported & - \\
\hline MIGS-4.2 & Longitude & Not reported & - \\
\hline MIGS-4.4 & Altitude & Not reported & - \\
\hline
\end{tabular}

aEvidence codes - IDA: Inferred from Direct Assay; TAS: Traceable Author Statement (i.e., a direct report exists in the literature); NAS: Non-traceable Author Statement (i.e., not directly observed for the living, isolated sample, but based on a generally accepted property for the species, or anecdotal evidence). These evidence codes are from the Gene Ontology project [57]

was isolated using the PowerSoil DNA Isolation Kit (Mobio, USA). All steps were performed according to the manufacture's instructions. Quality control of the isolated DNA was checked at GATC Biotech AG (Konstanz, Germany) prior to sequencing. A DNA concentration of $83.1 \mathrm{ng} / \mu \mathrm{l}$ and a $260 / 280$ ratio of 1.87 were determined.

\section{Genome sequencing and assembly}

Third generation sequencing technology from Pacific Biosciences was chosen for whole de novo genome sequencing of $T$. brockianus strain GE-1 because its continuous long reads of up to $10 \mathrm{~kb}$ covering the longest known bacterial and archaeal repetitive regions and thus facilitate the generation of complete bacterial genome 
Table 2 Project information

\begin{tabular}{lll}
\hline MIGS ID & Property & Term \\
\hline MIGS 31 & Finishing quality & Finished genome \\
MIGS-28 & Libraries used & PacBio RS library \\
MIGS 29 & Sequencing platforms & PacBio RS ॥ \\
MIGS 31.2 & Fold coverage & 156.56x PacBio \\
MIGS 30 & Assemblers & HGAP2 version 2.3.0 \\
MIGS 32 & Gene calling method & Prodigal v2.6 \\
& Locus Tag & A0O31 \\
& Genbank ID & CP016312, CP016313, CP016314 \\
& Genbank Date of Release & November 17, 2016 \\
& GOLD ID & Gp0134387 \\
& BIOPROJECT & PRJNA314486 \\
MIGS 13 & Source Material Identifier & GE_001 \\
& Project relevance & Biotechnological \\
\hline
\end{tabular}

assemblies [21, 22]. Library construction, quantification and sequencing were performed at GATC Biotech AG (Konstanz, Germany). A Pacbio RS library (8-12 kb) was constructed and one SMRT cell was used for sequencing. 86,479 subreads were obtained after filtering and a total of $447.6 \mathrm{Mb}$ with a N50 contig length of 2,058,948 bp were used for assembly. Pacific Biosciences sequencing data were assembled using an implemented version of PacBio SMRT Analysis, version 2.3.0 and the HGAP2 protocol (Pacific Biosciences, USA) [22]. Minimum seed read length was automatically determined by the protocol with a length cut-off of 10,819 bp. The sum of contig lengths was $2,431,825 \mathrm{bp}$. The final de novo assembly obtained three circular contigs, providing the complete genome sequence of T. brockianus strain GE-1 and genome coverage of 156.56. Each contig represented one replicon, including the chromosome (2,035,182 bp), the megaplasmid pTB1 (342,792 bp) and plasmid pTB2 $(10,299$ bp). Circularization of each replicon was checked and performed by using circlator [23]. Quality value of $>$ QV50 ( 1 error probability in 100,000 base calls) for each replicon was reached after several polishing steps using the quiver algorithm, included in PacBio SMRT Analysis, version 2.3.0 [22].

\section{Genome annotation}

Preliminary genome annotation was performed using the Prokka annotation pipeline v1.12 [24], followed by manual curation. Genes were identified by both Prodigal v2.6.3 [25] and Glimmer v3.0.2 [26]. Predicted coding sequences were translated and used to search the NCBI non-redundant database [27], UniProt [28] and Pfam [29] databases. The cmmscan and cmmsearch tools of the Hmmer3 package were used for protein similarity searches against HMM databases [30]. For COG classification RPS-BLAST was used to search against the COG database [31]. For rRNA detection we used RNAmmer v1.2 [32], while the tRNA prediction was performed by tRNAscan-SE v1.3.1 [33]. Non-coding RNAs and regulatory RNA features were identified by searching the genome for corresponding Ram profiles using INFERNAL v1.1.1 [34]. Signal peptides were identified by Signalp v4.1 [35] and clustered regularly interspaced short palindromic repeats (CRISPR) were detected by using MinCED v0.2.0 included in the Prokka annotation pipeline [36]. Analyses to identify genes that were assigned to transmembrane domains were performed by using tmhmm [37]. Circular maps were created using CGView [38].

\section{Genome properties}

The complete genome of $T$. brockianus GE-1 is composed of a single circular chromosome that consists of 2,035,182 bp and two circular plasmids, pTB1 and pTB2 (Fig. 3). The megaplasmid pTB1 has got 342,792 bp and the size of pTB2 is 10,299 bp (Table 3). The GC content of each replicon is 67.07 for the chromosome, 65.82 for megaplasmid pTB1 and 70.09 for plasmid pTB2. The $T$. brockianus GE-1 genome comprises 2,511 genes, including 2,458 protein-encoding genes (97.9\%), 53 RNAs (2.1\%) and 66 pseudo genes (2.6\%) (Table 4). In more detail there are 2,053 protein-encoding sequences for the chromosome, 299 for megaplasmid pTB1 and 13 for plasmid pTB2. Classification of genes into the COG functional categories is shown in Table 5.

\section{Insights from the genome sequence Comparison of genomes from $T$. brockianus GE-1 and other Thermus species}

Based on the availability of their finished genomes within the NCBI genome database we compare the $T$. brockianus GE-1 genome with six other Thermus species and seven genomes, including $T$. thermophilus HB8, T. thermophilus HB27 [39], T. scotoductus SA-01 [40], Thermus sp. CCB_US3_UF1 [41], T. oshimai JL-2 [42], T. aquaticus Y51MC23 [43] and T. parvatiensis [44]. With $2.38 \mathrm{Mb}$ the genome of T. brockianus GE-1 is the largest one of these finished genomes, close to the genomes of $T$. oshimai JL-2 $(2.33 \mathrm{Mb}), T$. aquaticus Y51MC23 (2.34 Mb) and T. scotoductus SA-01 (2.36 Mb) and much bigger than Thermus sp. CCB_US3_UF1 (2.26 Mb), T. thermophilus HB8 (2.12 Mb), T. thermophilus HB27 $(2.13 \mathrm{Mb})$ and T. parvatiensis $(2.03 \mathrm{Mb})$. All of those finished genomes include a chromosome and at least one plasmid. The genome of $T$. brockianus GE-1 consists of one chromosome $(2.04 \mathrm{Mb})$ and two plasmids, including megaplasmid pTB1 $(0.34 \mathrm{Mb})$ and plasmid pTB2 $(10 \mathrm{~kb})$. In number and size of those replicons the genome of $T$. brockianus GE-1 is similar to T. thermophilus HB8 having a 


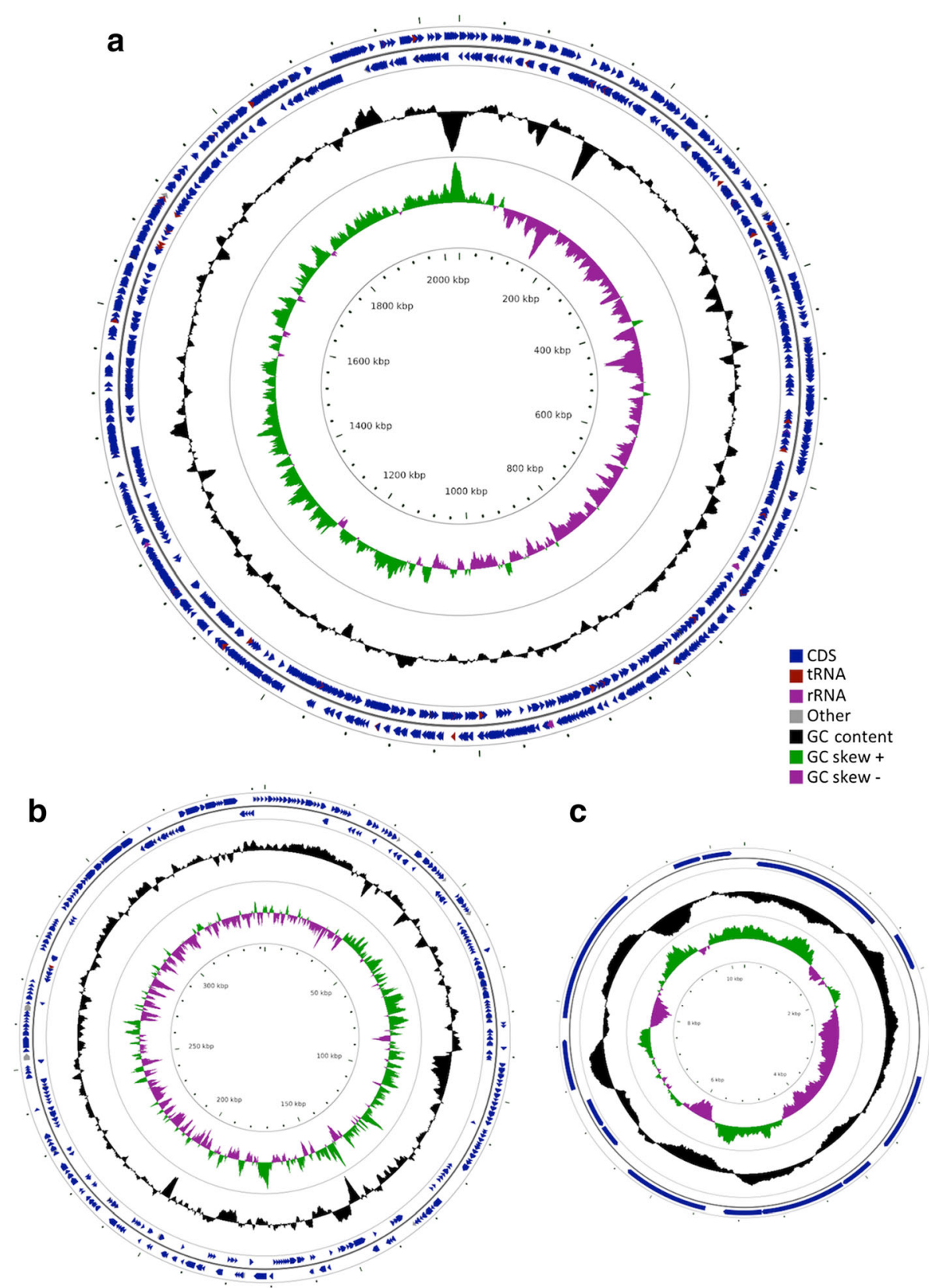

Fig. 3 Graphical circular maps of T. brockianus GE-1 replicons. The complete genome of T. brockianus GE-1 is composed of a single circular chromosome that consists of 2,035,182 bp (a) and two circular plasmids, pTB1 (b) and pTB2 (c). The size of megaplasmid pTB1 is 342,792 bp and 10,299 bp for pTB2. These maps were generated by using CGView [38]. Data shown on those maps will be explained from the inside to the outside: Second circle represents the GC skew of both strands (green for plus strand, purple for minus strand) and the fourth circle shows the GC content. The sixth and seventh circle exhibits the protein-encoding genes for the plus and minus strand as well as RNA features. All tRNAs are highlighted in orange, rRNAs are shown in light purple and other RNAs are represented by a grey color

Table 3 Summary of the genome of Thermus brockianus GE-1: 1 chromosome and 2 plasmids

\begin{tabular}{lllll}
\hline Label & Size $(\mathrm{Mb})$ & Topology & INSDC identifier & RefSeq ID \\
\hline Chromosome & 2.035 & circular & CP016312 & - \\
pTB1 & 0.343 & circular & CP016313 & - \\
PTB2 & 0.010 & circular & CP016314 & - \\
\hline
\end{tabular}

chromosome (1.85 Mb), the megaplasmid pTT27 $(0.26 \mathrm{Mb})$ and the plasmid pTT8 $(9.3 \mathrm{~kb})$ as well as $T$. oshimai JL-2 with one chromosome $(2.07 \mathrm{Mb})$, one megaplasmid pTHEOS01 (0.27 Mb) and one plasmid pTHEOS02 (6 kb). Megaplasmids are a common feature of Thermus spp., since they were also identified in T. thermophilus HB27 (pTT27; $0.23 \mathrm{Mb}$ ) and T. parvatiensis 
Table 4 Genome statistics

\begin{tabular}{lll}
\hline Attribute & Value & \% of Total \\
\hline Genome size (bp) & $2,388,273$ & 100.0 \\
DNA coding (bp) & $2,217,408$ & 92.9 \\
DNA G + C (bp) & $1,597,811$ & 67.0 \\
DNA scaffolds & 3 & 100.0 \\
Total genes & 2,511 & 100.0 \\
Protein coding genes & 2,458 & 97.9 \\
RNA genes & 53 & 2.1 \\
Pseudo genes & 66 & 2.6 \\
Genes in internal clusters & 66 & - \\
Genes with function prediction & 1,834 & 73.0 \\
Genes assigned to COGs & 1,948 & 77.6 \\
Genes with Pfam domains & 1,736 & 69.1 \\
Genes with signal peptides & 112 & 4.5 \\
Genes with transmembrane helices & 561 & 22.3 \\
CRISPR repeats & 8 & 0.3 \\
\hline
\end{tabular}

${ }^{a}$ The total is based on either the size of the genome in base pairs or the total genes in the annotated genome

${ }^{\mathrm{b}}$ Pseudo genes may also be counted as protein coding or RNA genes, so is not additive under total gene count

(pTP143; 0.14 Mb). Due to their thermophilic lifestyle, all finished Thermus genomes exhibit a high GC content varying between $64.9 \%$ for $T$. scotoductus SA-01 and $69.5 \%$ for T. thermophilus HB8 with an average value of $67.0 \%$ GC content for the genome of T. brockianus GE-1.

With its total gene number of 2,511 and 2,458 protein-encoding genes, the genome of $T$. brockianus GE-1 showed high-ranking numbers in comparison to the available genomes, comparable to $T$. oshimai JL-2 (2,580 in total and 2,436 protein-encoding genes), $T$. scotoductus SA-1 (2,511 and 2,458), T. aquaticus Y51MC23 (2,484 and 2,325) and higher than Thermus sp. CCB_US3_UF1 (2,333 and 2,279), T. thermophilus HB8 (2,226 and 2,173), T. thermophilus HB27 (2,263 and $2,210)$ and $T$. parvatiensis $(1,573$ and 2,190$)$. The genome of T. brockianus GE-1 encodes 47 tRNA genes and 6 rRNA genes, similar to most of the other finished genomes. Additionally, eight clustered regularly interspaced short palindromic repeats (CRISPRs) were identified in the genome of $T$. brockianus GE-1, suggesting the presence of a defense mechanism against phage DNA invasion, equivalent to other finished Thermus genomes with reported CRISPR sequences, including Thermus sp. CCB_US3_UF1 (8), T. thermophilus HB8 (11) and HB27 (10) and T. scotoductus SA-01 (3) [41].

By whole genome comparison analyses we identified the highest number of protein orthologs in the genomes of $T$ oshimai (85.86\%) and T. aquaticus (85.34\%). These two genomes shared 2,156 and 2,143 of the 2,511 total proteins with T. brockianus GE-1. Further comparisons
Table 5 Number of genes associated with general COG functional categories

\begin{tabular}{|c|c|c|c|}
\hline Code & Value & \%age & Description \\
\hline J & 143 & 5.81 & $\begin{array}{l}\text { Translation, ribosomal structure } \\
\text { and biogenesis }\end{array}$ \\
\hline A & 0 & 0.00 & RNA processing and modification \\
\hline K & 87 & 3.54 & Transcription \\
\hline L & 106 & 4,31 & Replication, recombination and repair \\
\hline B & 2 & 0.08 & Chromatin structure and dynamics \\
\hline D & 28 & 1.14 & $\begin{array}{l}\text { Cell cycle control, Cell division, } \\
\text { chromosome partitioning }\end{array}$ \\
\hline V & 27 & 1.10 & Defense mechanisms \\
\hline $\mathrm{T}$ & 71 & 2.89 & Signal transduction mechanisms \\
\hline M & 84 & 3.42 & Cell wall/membrane biogenesis \\
\hline N & 14 & 0.57 & Cell motility \\
\hline U & 18 & 0.73 & Intracellular trafficking and secretion \\
\hline O & 84 & 3.42 & $\begin{array}{l}\text { Posttranslational modification, protein } \\
\text { turnover, chaperones }\end{array}$ \\
\hline C & 155 & 6.31 & Energy production and conversion \\
\hline G & 123 & 5.00 & Carbohydrate transport and metabolism \\
\hline $\mathrm{E}$ & 207 & 8.42 & Amino acid transport and metabolism \\
\hline $\mathrm{F}$ & 70 & 2.85 & Nucleotide transport and metabolism \\
\hline $\mathrm{H}$ & 107 & 4.35 & Coenzyme transport and metabolism \\
\hline । & 78 & 3.17 & Lipid transport and metabolism \\
\hline$P$ & 100 & 4.07 & Inorganic ion transport and metabolism \\
\hline Q & 23 & 0.94 & $\begin{array}{l}\text { Secondary metabolites biosynthesis, } \\
\text { transport and catabolism }\end{array}$ \\
\hline $\mathrm{R}$ & 253 & 10.29 & General function prediction only \\
\hline$S$ & 168 & 6.83 & Function unknown \\
\hline - & 510 & 20.75 & Not in COGs \\
\hline
\end{tabular}

The total is based on the total number of protein coding genes in the genome

revealed $83.07 \%$ protein orthologs in comparison to Thermus sp. CCB_US3_UF1 (2,086 of 2,511), $82.44 \%$ to T. scotoductus (2,070 of 2,511$), 81.96 \%$ to $T$. thermophilus HB8 $(2,058$ of 2,511$)$ and $81.76 \%$ to T. thermophilus HB27 (2,053 of 2,511). With 1,661 and $66.15 \%$ we identified the lowest numbers of protein orthologs between $T$. parvatiensis and T. brockianus GE-1.

The number of total and protein-encoding genes on megaplasmid pTB1 were 314 and 299 as well as 13 for both in case of pTB2. Especially, the number of genes on the megaplasmid pTB1 is much higher compared to other available megaplasmids, since their total gene numbers vary between 150 (T. parvatiensis) and 251 ( $T$. thermophilus HB8). These differences are explicable by the smaller size of both megaplasmids $(0.14 \mathrm{Mb}$ for pTP143 and $0.26 \mathrm{MB}$ for pTT27) in comparison to pTB1 $(0.34 \mathrm{Mb})$. In contrast, the size of pTB2 $(10 \mathrm{~kb})$ is smaller than most other additional plasmids, which were reported to be 6-60 kb. 
General metabolic pathways were investigated by KEGG analysis and revealed complete sets of genes for glycolysis, gluconeogenesis, citrate cycle, pentose phosphate pathway as well as genes involved in the lipid-, nucleotide-, amino acid-, cofactor- and vitaminmetabolism. For nutrient uptake, we identified 14 ABC transporters. All of these genes were localized on the chromosome of T. brockianus GE-1.

\section{Xylan degradation pathway}

Thermophilic bacteria like T. brockianus are of great industrial relevance, because they produce heat-stable and heat-active enzymes, so called thermozymes that perfectly match harsh process conditions. With regard to biocatalysts with a great potential for biotechnological processes, e.g. biorefinery, we identified sequences encoding putative lipases, subtilisin-like proteases, glucosidases and galactosidases in the genome of $T$. brockianus GE-1. The observed ability of this strain to degrade xylan-rich substrates and the identification of the responsible xylanase Xyn10 in our previous study directed our interest towards the investigation of the xylan degradation pathway by performing an analysis of the whole genome sequence of T. brockianus GE-1 [14]. Interestingly, there is no homologue xylanase sequence detectable in any other Thermus genome that is currently available. Thus, the amino acid sequence of the xylanase Xyn10 from T. brockianus strain GE-1 displays the highest identity (57\%) to a 1,4- $\beta$ xylanase from Streptomyces sp. NRRL WC-3723. These two organisms are not closely related but it can be hypothesized that due to similar environmental conditions an ancestor of T. brockianus obtained the coding sequence of xyn 10 by horizontal gene transfer. Another interesting fact to consider is that the localization of the corresponding gene xyn10 was not detected on the bacterial chromosome like other hydrolases, including lipases, peptidases and ATPases.

Further investigations of the genomic region revealed an unique set of genes related to cellulose degradation and xylose metabolism adjacent to xyn10, including a putative endoglucanase as well as membrane $A B C$ sugar transporter encoded by $x y l H, x y l F$ encoding the xylose binding protein, the xylose repressor encoding gene $x y l R$, the xylose isomerase encoding gene $x y l A$ and the gene $x y l B$ coding for a xylulokinase (Fig. 4). Especially the latter ones are of great importance, since XylA catalyzes the first step of the xylose metabolism by isomerization of xylose to xylulose, while XylB is responsible for the second step, phosphorylating xylulose to xylulose-5-phosphate $[45,46]$. These xylose metabolismrelated genes are conserved in other Thermus spp. genomes and a similar set has been described for plasmid pVV8 in the genome of T. thermophilus HB8 $[46,47]$. Genome comparison studies of pVV8 and pTB1 revealed $75 \%$ identity of the genomic region encoding the xylose metabolism-related genes. However, the xylanase, the endoglucanase and the $\mathrm{ABC}$ transporter systemassociated genes are described for the first time in a Thermus species genome. These genes showed highest similarities (43\% to $57 \%)$ to distantly related genera including Streptomyces and Alicyclobacillus. The absence of a $\beta$-xylosidase in the genome of T. brockianus GE-1 is explicable by the $\beta$-xylosidase side activity of xylanase Xyn10, thus breaking down xylan directly to D-xylose [14]. Altogether the localization of this whole set of genes on the megaplasmid PTB1 in combination with the non-essential character of the xylan degradation pathway for the lifestyle of $T$. brockianus GE-1 indicates that $T$. brockianus GE-1 has gained the xylanolytic ability as a beneficial advantage, probably via horizontal gene transfer in an ancestor of T. brockianus. In accordance to the bioconversion of lignocellulosic biomass, another interesting point to consider is the identification of a putative endoglucanase. By linking genes encoding endoglucanase and xylanase on its megaplasmid pTB1, these enzymes might act in concert in a synergistically fashion. Especially, in regard to a recent report of an evolved strain of $T$. thermophilus co-utilizing xylose and glucose [16], T. brockianus GE-1 and its unique genomic linkage of sequences encoding key enzymes for xylan and cellulose degradation as well as for xylose metabolism seems to be of great interest for biotechnical applications and thus will be examined in prospective studies.

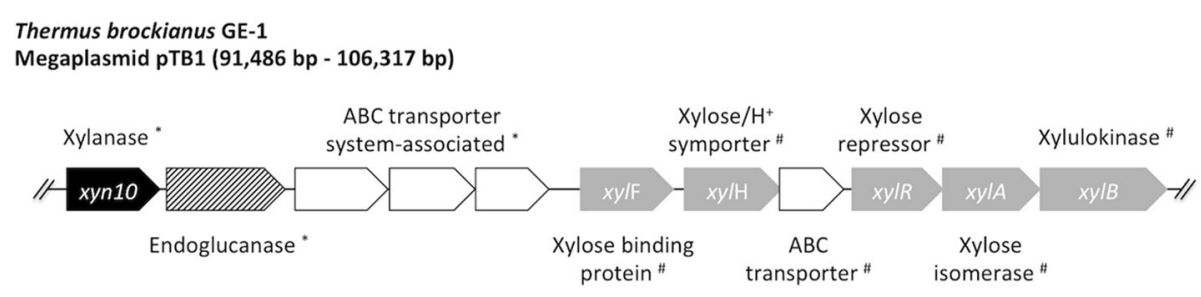

Fig. 4 Genomic organization of genes encoding proteins for xylan and cellulose degradation as well as xylose metabolism located on the megaplasmid pTB1 of T. brockianus GE-1. Sizes, localization and orientation of the genes on megaplasmid pTB1 section are displayed proportionally. All genes highlighted with a star are not detectable in any other Thermus spp. genome except T. brockianus GE-1. Genes marked with a diamond are conserved in Thermus spp. $A B C$ transporter system associated genes include sugar $A B C$ transporter substrate-binding protein and two sugar $A B C$ transporter permeases 


\section{Conclusions}

Thermus spp. and their extremozymes are of great interest for a wide set of industrial applications. Here we present the first whole genome sequence of $T$. brockianus GE-1, providing further insights into the biotechnological potential of the genus Thermus spp. in general and $T$. brockianus GE-1 specifically. The genome of T. brockianus GE-1 consists of a chromosome and two plasmids, including the megaplasmid pTB1. Sequences coding for essential metabolism pathways like glycolysis, gluconeogenesis, pentose phosphate pathway or citrate cycle were assigned to the bacterial chromosome just as well as sequences encoding industrial relevant enzymes, including galactosidases, glucosidases, lipases and subtilisin-like proteases. These novel extremozymes will be targets of prospective characterization studies to prove their industrial relevance. However, localization of gene xyn10 coding for a previously described xylanase from $T$. brockianus GE-1 was not detected on the chromosome but on the megaplasmid pTB1 adjacent to sequences encoding key enzymes for cellulose degradation and xylose metabolism. Thus, in accordance to a reported $\beta$-xylosidase side activity of xylanase Xyn10 the complete breakdown of xylan to D-xylose is genetically linked to the xylose metabolism in the genome of T. brockianus GE-1. These findings are consistent with the described xylanolytic activity of T. brockianus GE-1. The described combination of the identification of novel sequences encoding putative biocatalysts on the one hand and the description of a xylanolytic degradation pathway on the other hand emphasize the importance of Thermus spp. as promising sources of extremozymes with potential industrial value.

\section{Abbreviations}

COG: Clusters of Orthologous Groups; CRISPR: Clustered regularly interspaced short palindromic repeats; QV: Quality value

\section{Acknowledgements}

The authors thank Milton Simões da Costa for the kind gift of strain Thermus brockianus GE-1. We also thank Carola Schröder for discussion and critical reading of the manuscript. This publication was supported by the German Research Foundation (DFG) and the Hamburg University of Technology $(\mathrm{TUHH})$ in the funding programme "Open Access Publishing".

\section{Authors' contributions}

CS, SE and GA conceived and designed the analysis. CS performed the complete genome production, including genome assembly, annotation and GenBank submission. SB and SW prepared the DNA isolation and the cultivation of Thermus brockianus strain GE-1. SW performed the microscopic studies of Thermus brockianus strain GE-1. SE and CS worked on phylogenetics and pathway analyses. GA provided reagents and tools. CS drafted the manuscript. All authors read and approved the final manuscript.

\section{Competing interests}

The authors declare that they have no competing interests.

Received: 24 November 2016 Accepted: 23 December 2016 Published online: 03 February 2017

\section{References}

1. Antranikian G, Egorova K. Extremophiles, a unique source of biocatalysts for industrial biotechnology. In: Gerday C, Glansdorff N, editors. Physiology and Biochemistry of Extremophiles. ASM Press: Wahington D.C; 2007. p. 361-406.

2. Elleuche S, Schäfers C, Blank S, Schröder C, Antranikian G. Exploration of extremophiles for high temperature biotechnological processes. Curr Opin Microbiol. 2015;25:113-9.

3. Madigan MT, Marrs BL. Extremophiles. Sci Am. 1997;276:82-7.

4. Vieille C, Zeikus GJ. Hyperthermophilic enzymes: sources, uses, and molecular mechanisms for thermostability. Microbiol Mol Biol Rev. 2001;65:1-43.

5. Brock TD, Freeze H. Thermus aquaticus gen. n. and sp. n., a nonsporulating extreme thermophile. J Bacteriol. 1969;98:289-97.

6. Schäfers C, Elleuche S, Antranikian G. Biochemical Properties and Applications of Heat-active Biocatalysts. In: Li F-L, editor. Thermophilic Microorganisms. Norfolk: Caister Academic Press; 2015. p. 47-90.

7. Cava F, Hidalgo A, Berenguer J. Thermus thermophilus as biological model. Extremophiles. 2009;13:213-31.

8. Sazanov LA, Hinchliffe P. Structure of the hydrophilic domain of respiratory complex I from Thermus thermophilus. Science. 2006:311:1430-6.

9. Matsuzawa H, Tokugawa K, Hamaoki M, Mizoguchi M, Taguchi H, Terada I, et al. Purification and characterization of aqualysin I (a thermophilic alkaline serine protease) produced by Thermus aquaticus YT-1. Eur J Biochem. 1988;171:441-7.

10. Bruins ME, Janssen AE, Boom RM. Thermozymes and their applications: a review of recent literature and patents. Appl Biochem Biotechnol. 2001;90:155-86.

11. Lee SH, Minagawa E, Taguchi H, Matsuzawa H, Ohta T, Kaminogawa S, et al. Purification and characterization of a thermostable carboxypeptidase (carboxypeptidase Taq) from Thermus aquaticus YT-1. Biosci Biotechnol Biochem. 1992:56:1839-44.

12. Minagawa E, Kaminogawa S, Matsuzawa H, Ohta T, Yamauchi K. Isolation and Characterization of a Thermostable Aminopeptidase (Aminopeptidase T) from Thermus aquaticus YT-1, an Extremely Thermophilic Bacterium (Biological Chemistry). Agric Biol Chem. 1988:52:1755-63.

13. Schröder C, Blank S, Antranikian G. First Glycoside Hydrolase Family 2 Enzymes from Thermus antranikianii and Thermus brockianus with betaGlucosidase Activity. Front Bioeng Biotechnol. 2015;3:76.

14. Blank S, Schröder C, Schirrmacher G, Reisinger C, Antranikian G. Biochemical characterization of a recombinant xylanase from Thermus brockianus, suitable for biofuel production. JSM Biotechnol Biomed Eng. 2014:2:1027.

15. Chung AP, Rainey FA, Valente M, Nobre MF, da Costa MS. Thermus igniterrae sp. nov. and Thermus antranikianii sp. nov., two new species from Iceland. Int J Syst Evol Microbiol. 2000;50 Pt 1:209-17.

16. Cordova LT, Lu J, Cipolla RM, Sandoval NR, Long CP, Antoniewicz MR. Coutilization of glucose and xylose by evolved Thermus thermophilus LC113 strain elucidated by (13)C metabolic flux analysis and whole genome sequencing. Metab Eng. 2016;37:63-71.

17. Lyon PF, Beffa T, Blanc M, Auling G, Aragno M. Isolation and characterization of highly thermophilic xylanolytic Thermus thermophilus strains from hot composts. Can J Microbiol. 2000;46:1029-35.

18. Huang XQ, Miller W. A Time-Efficient, Linear-Space Local Similarity Algorithm. Advances in Applied Mathematics. 1991;12:337-57.

19. Da Costa MS, Rainey FA, Nobre MF. The Genus Thermus and Relatives. In: Dworkin M, et al., Editors. The Prokaryotes: Volume 7: Proteobacteria: Delta, Epsilon Subclass. New York: Springer New York; 2006. p. 797-812.

20. Field D, Garrity G, Gray T, Morrison N, Selengut J, Sterk P, et al. The minimum information about a genome sequence (MIGS) specification. Nat Biotechnol. 2008;26:541-7.

21. Treangen TJ, Abraham AL, Touchon M, Rocha EP. Genesis, effects and fates of repeats in prokaryotic genomes. FEMS Microbiol Rev. 2009;33:539-71.

22. Chin CS, Alexander DH, Marks P, Klammer AA, Drake J, Heiner C, et al. Nonhybrid, finished microbial genome assemblies from long-read SMRT sequencing data. Nat Methods. 2013;10:563-9.

23. Hunt M, Silva ND, Otto TD, Parkhill J, Keane JA, Harris SR. Circlator: automated circularization of genome assemblies using long sequencing reads. Genome Biol. 2015;16:294.

24. Seemann T. Prokka: rapid prokaryotic genome annotation. Bioinformatics. 2014:30:2068-9.

25. Hyatt D, Chen GL, Locascio PF, Land ML, Larimer FW, Hauser L. Prodigal: prokaryotic gene recognition and translation initiation site identification. BMC Bioinformatics. 2010;11:119. 
26. Delcher AL, Bratke KA, Powers EC, Salzberg SL. Identifying bacterial genes and endosymbiont DNA with Glimmer. Bioinformatics. 2007;23:673-9.

27. Altschul SF, Gish W. Local alignment statistics. Methods Enzymol. 1996;266: 460-80.

28. Apweiler R, Bairoch A, Wu CH, Barker WC, Boeckmann B, Ferro S, et al. UniProt: the Universal Protein knowledgebase. Nucleic Acids Res. 2004;32:D115-9.

29. Finn RD, Coggill P, Eberhardt RY, Eddy SR, Mistry J, Mitchell AL, et al. The Pfam protein families database: towards a more sustainable future. Nucleic Acids Res. 2016:44:D279-85.

30. Eddy SR. Profile hidden Markov models. Bioinformatics. 1998;14:755-63.

31. Marchler-Bauer A, Lu S, Anderson JB, Chitsaz F, Derbyshire MK, DeWeeseScott C, et al. CDD: a Conserved Domain Database for the functional annotation of proteins. Nucleic Acids Res. 2011;39:D225-9.

32. Lagesen $K$, Hallin P, Rodland EA, Staerfeldt HH, Rognes T, Ussery DW. RNAmmer: consistent and rapid annotation of ribosomal RNA genes. Nucleic Acids Res. 2007;35:3100-8.

33. Lowe TM, Eddy SR. tRNAscan-SE: a program for improved detection of transfer RNA genes in genomic sequence. Nucleic Acids Res. 1997;25:955-64.

34. Nawrocki EP, Kolbe DL, Eddy SR. Infernal 1.0: inference of RNA alignments. Bioinformatics. 2009;25:1335-7.

35. Petersen TN, Brunak S, von Heijne G, Nielsen H. SignalP 4.0: discriminating signal peptides from transmembrane regions. Nat Methods. 2011:8:785-6.

36. Bland C, Ramsey TL, Sabree F, Lowe M, Brown K, Kyrpides NC, et al. CRISPR recognition tool (CRT): a tool for automatic detection of clustered regularly interspaced palindromic repeats. BMC Bioinformatics. 2007:8:209.

37. Krogh A, Larsson B, von Heijne G, Sonnhammer EL. Predicting transmembrane protein topology with a hidden Markov model: application to complete genomes. J Mol Biol. 2001;305:567-80.

38. Stothard P, Wishart DS. Circular genome visualization and exploration using CGView. Bioinformatics. 2005:21:537-9.

39. Henne A, Brüggemann $H$, Raasch C, Wiezer A, Hartsch T, Liesegang H, et al. The genome sequence of the extreme thermophile Thermus thermophilus. Nat Biotechnol. 2004;22:547-53.

40. Gounder K, Brzuszkiewicz E, Liesegang H, Wollherr A, Daniel R, Gottschalk G, et al. Sequence of the hyperplastic genome of the naturally competent Thermus scotoductus SA-01. BMC Genomics. 2011;12:577.

41. Teh BS, Lau NS, Ng FL, Abdul Rahman AY, Wan X, Saito JA. Complete genome sequence of the thermophilic Thermus sp. CCB_US3_UF1 from a hot spring in Malaysia. Stand Genomic Sci. 2015;10:76.

42. Murugapiran SK, Huntemann M, Wei CL, Han J, Detter JC, Han CS, et al. Whole Genome Sequencing of Thermus oshimai JL-2 and Thermus thermophilus $\lrcorner$-18, Incomplete Denitrifiers from the United States Great Basin. Genome Announc. 2013;1.

43. Brumm PJ, Monsma S, Keough B, Jasinovica S, Ferguson E, Schoenfeld T, et al. Complete Genome Sequence of Thermus aquaticus Y51MC23. PLoS One. 2015;10, e0138674.

44. Dwivedi V, Sangwan N, Nigam A, Garg N, Niharika N, Khurana P, et al. Draft genome sequence of Thermus sp. strain $\mathrm{RL}$, isolated from a hot water spring located atop the Himalayan ranges at Manikaran, India. J Bacteriol. 2012;194:3534

45. Biely P. Microbial Xylanolytic Systems Trends in Biotechnology. 1985:3:286-90

46. Wu YW, Joshua C, Eichorst SA, Gladden JM, Simmons BA, Singer SW. Genomic Analysis of Xylose Metabolism in Members of the DeinoccocusThermus Phylum from Thermophilic Biomass-Deconstructing Bacterial Consortia. Bioenergy Res. 2015;8:1031-8.

47. Ohtani N, Tomita M, Itaya M. The third plasmid pW8 from Thermus thermophilus HB8: isolation, characterization, and sequence determination. Extremophiles. 2012;16:237-44.

48. Woese CR, Kandler O, Wheelis ML. Towards a natural system of organisms: proposal for the domains Archaea, Bacteria, and Eucarya. Proc Natl Acad Sci U S A. 1990;87:4576-9

49. Skerman VBD, Mcgowan V, Sneath PHA. Approved Lists of Bacterial Names. Int J Syst Bacteriol. 1980;30:225-420

50. Weisburg WG, Giovannoni SJ, Woese CR. The Deinococcus-Thermus phylum and the effect of rRNA composition on phylogenetic tree construction. Syst Appl Microbiol. 1989;11:128-34

51. Garrity GM. Validation of publication of new names and new combinations previously effectively published outside the IJSEM. Int I Syst Evol Microbiol. 2005;55:2235-8.
52. Garrity GM, Holt JG. Class I. Deinococci class. nov. In: Garrity GM, Boone DR, Castenholz RW, editors. Bergey's Manual of Systematic Bacteriology, vol. 1. 2nd ed. New York: Springer; 2001. p. 395.

53. Rainey FA, da Costa MS. Thermalesord. nov. Bergey's Manual of Systematics of Archaea and Bacteria. John Wiley \& Sons, Ltd.; 2015. doi:10.1002/ $9781118960608.0 b m 00045$.

54. Da Costa M, Rainey F, Family I. Thermaceae fam. nov. Bergey's Manual of Systematic Bacteriology. 2001;1:403-4

55. Nobre MF, Trüper HG, da Costa MS. Transfer of Thermus ruber (Loginova et al. 1984), Thermus silvanus (Tenreiro et al. 1995), and Thermus chliarophilus (Tenreiro et al. 1995) to Meiothermus gen. nov. as Meiothermus ruber comb, nov., Meiothermus silvanus comb. nov., and Meiothermus chliarophilus comb. nov., respectively, and emendation of the genus Thermus. Int J Syst Evol Microbiol. 1999;49:1951-1.

56. Williams RA, Smith KE, Welch SG, Micallef J, Sharp RJ. DNA relatedness of Thermus strains, description of Thermus brockianus sp. nov., and proposal to reestablish Thermus thermophilus (Oshima and Imahori). Int J Syst Bacteriol. 1995;45:495-9.

57. Ashburner M, Ball CA, Blake JA, Botstein D, Butler H, Cherry JM, et al. Gene ontology: tool for the unification of biology. The Gene Ontology Consortium Nat Genet. 2000;25:25-9.

58. Felsenstein J. PHYLIP: phylogenetic inference package [3.6]. Seattle, WA: University of Washington; 1991.

59. Page RD. Visualizing phylogenetic trees using TreeView. Curr Protoc Bioinformatics, 2002; Chapter 6:Unit 62.

60. Larkin MA, Blackshields G, Brown NP, Chenna R, McGettigan PA, McWilliam $H$, et al. Clustal W and Clustal X version 2.0.. Bioinformatics. 2007;23:2947-8.

\section{Submit your next manuscript to BioMed Central and we will help you at every step:}

- We accept pre-submission inquiries

- Our selector tool helps you to find the most relevant journal

- We provide round the clock customer support

- Convenient online submission

- Thorough peer review

- Inclusion in PubMed and all major indexing services

- Maximum visibility for your research

Submit your manuscript at www.biomedcentral.com/submit 